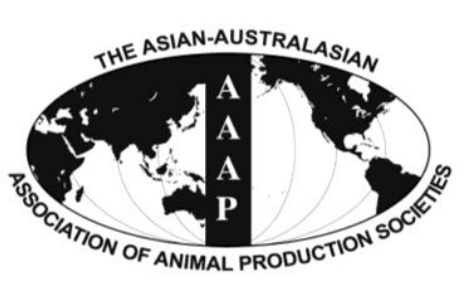

\begin{tabular}{c} 
Open Access \\
Asian Australas. J. Anim. Sci. \\
Vol. 28, No. 8 : 1095-1104 August 2015 \\
http://dx.doi.org/10.5713/ajas.14.0865 \\
\hline www.ajas.info \\
pISSN 101 1-2367 elSSN 1976-5517
\end{tabular}

\title{
Pelleting in Associated with Sodium Monensin Increases the Conjugated Linoleic Acids Concentration in the Milk of Dairy Cows Fed Canola Seeds
}

\author{
Francilaine Eloise De Marchi, Jakeline Vieira Romero, Julio Cesar Damasceno, Paula Adriana Grande, \\ Lúcia Maria Zeoula, and Geraldo Tadeu dos Santos* \\ Programa de Pós-Graduação em Zootecnia, Universidade Estadual de Maringá, Maringá, PR 87020-900, Brazil
}

\begin{abstract}
To evaluate the effects of the pelleting and the addition of sodium monensin on production, the chemical and lipid composition of milk and butter physical characteristics, 4 Holstein dairy cows (135 days of lactation) with an average milk production of $14.7 \mathrm{~kg} / \mathrm{d}$, were supplemented with a concentrate containing ground canola seeds. The cows were assigned to a $4 \times 4$ Latin square design with a $2 \times 2$ factorial arrangement of treatments: i) ground maize, soybean meal, mineral and vitamin supplements, and ground canola seeds (CG); ii) CG concentrate with $31.5 \mathrm{mg}$ of monensin added per $\mathrm{kg}$ of dry matter (DM); iii) CG pelleted concentrate; iv) CG concentrate with monensin addition pelleted. There was no difference in milk production and composition. The addition of monensin increased milk concentration of polyunsaturated fatty acids (PUFA), the PUFA/saturated fatty acids (SFA) ratio, and omega 6. The pelleting increased the concentration of monounsaturated fatty acids, the PUFA/SFA ratio, and the omega 6/omega 3 ratio, but decreased the concentration of SFA. The association between pelleting and the addition of monensin increased the concentration of conjugated linoleic acids by $46.9 \%$. The physical characteristics of butter were not affected by the evaluated diets. We concluded that the concentrate with $31.5 \mathrm{mg}$ of monensin added per $\mathrm{kg}$ DM basis combined with the pelleting improves the lipid composition of milk from Holstein cows that are on pasture and supplemented with ground canola seeds, without changing the production, milk composition, and spreadability of butter. (Key Words: Animal Production, Ionophore, Heat Treatment, Polyunsaturated Fatty Acid)
\end{abstract}

\section{INTRODUCTION}

Fatty acids (FA) of the omega 3 and omega 6 families as well as conjugated linoleic acids (CLA) and its isomers have been shown to have an important function in preventing human diseases (Cichosz and Czeczot, 2012). Ruminant's milk fat is the richest CLA natural source, and in bovine milk the isomer $\mathrm{C} 18: 2$ cis-9 trans-11 represents an average $90 \%$ of the known isomers and it can be influenced by many sources of variations (Parodi, 2009).

The addition of oilseeds or their oils in the diet of dairy cows have been effective in improving milk fatty acid profile because they decrease saturated fatty acids (SFA)

\footnotetext{
* Corresponding Author: Geraldo Tadeu dos Santos. Tel: +55-4430118947, E-mail: gtsantos50@gmail.com

Submitted Nov. 11, 2014; Revised Jan. 9, 2015; Accepted Feb. 10, 2015
}

and increase polyunsaturated fatty acids (PUFA) levels in the form of CLA, omega 3, and omega 6 FA (Mohammed et al., 2011). Another factor that can potentiate this increase is keeping animals on pasture (Schroeder et al., 2004); because $\alpha$-linolenic and linoleic FA are abundant in grasses. These FA are CLA precursors during the ruminal biohydrogenation process and in the mammary gland.

Canola is an oilseed that, despite the high oil content $(55 \%)$, is considered a protein source for ruminants $(20 \%$ crude protein [CP]) and is rich in PUFA. Based on the total FA, the oil is composed of around 60\% oleic acid (omega 9), $20 \%$ linoleic acid (omega 6), and 10\% linolenic acid (omega 3; Canola Council of Canada, 2015). However, canola seed has low digestibility, unless the hull is broken and the core exposed. In this case, PUFA are exposed for ruminal biohydrogenation. Thus, if ruminal biohydrogenation can be controlled, it will be possible to 
increase the transfer of these PUFA for milk and milk derivatives.

The processing of concentrated feeds via thermal treatments, as the pelleting, is an alternative method to protect canola PUFA from ruminal biohydrogenation, and to improve nutrient digestibility of the diet (Neves et al., 2007; Neves et al., 2009; dos Santos et al., 2011). Another alternative is the use of ionophores that, in addition to improving energy metabolism, reducing the ruminal degradation of dietary protein, increasing the digestibility and milk production, also reduce SFA and increase CLA content in the milk of dairy cows (Duffield et al., 2008; da Silva-Kazama et al., 2011). Despite the recent questionings from the World Health Organization about the addition of antibiotics in animal feed and the preventive prohibition on its use by the European Union in 2006 (Regulation [EC] No 1831/2003), monensin is a feed additive permitted by US. Food and Drug Admistration since 2005 (FDA, 2005, Freedom of Information Summary - NADA 095-735) and by Food and Agriculture Organization of the United Nations (FAO). Data collected by FAO show that the monensin, when used in the appropriate doses, doesn't leaves residues in ruminant milk or remains below to maximum residue limits, not being in that way a risk to human health (Bizec and Sanders, 2009). In Brazil, Australia, Canada, New Zealand and others countries monensin addition in animal feed is permitted. Thus, our hypothesis is that the pelleting and the addition of monensin can increase milk production and improve milk lipid composition; moreover, these effects can be potentiated through the association of the two treatments. Therefore, we aimed to evaluate the effects of the pelleting and the addition of monensin on intake, apparent nutrient digestibility, milk production, milk chemical and lipid composition, and butter texture in Holstein cows on pasture and supplemented with concentrate containing ground canola seeds.

\section{MATERIALS AND METHODS}

\section{Animals and experimental diets}

This study was conducted at the experimental farm of the Universidade Estadual de Maringá, southern Brazil. The Animal Care and Use Committee of the Universidade Estadual de Maringá approved all animal procedures. Four primiparous Holstein cows (134.8 \pm 64 lactation days), with an average weight of $449.8 \pm 5.3 \mathrm{~kg}$ in the beginning of the experiment and an average milk production of $14.7 \pm 1.4$ $\mathrm{kg} / \mathrm{d}$ were distributed in a Latin square design with four 21d periods, which was comprised of 16 days for acclimation and 5 days for collections. The animals were kept on rotational grazing with free access to water. Twice daily (6:00 $\mathrm{h}$ and 15:00 h), cows were taken to be milked, after which they were housed in a tie stall type system, for around $3 \mathrm{~h}$, in order to provide the concentrate. The concentrate treatments were: i) ground corn, soybean meal, mineral and vitamin supplements, and ground canola seeds (CG); ii) concentrate $\mathrm{CG}$ with the addition of $31.5 \mathrm{mg}$ of monensin/kg dry matter (DM) of concentrate (CGM); iii) concentrate $\mathrm{CG}$ pelleted (CGP); iv) concentrate $\mathrm{CG}$ with monensin addition pelleted (CMP) (Table 1). The canola and corn grains were ground through a $5 \mathrm{~mm}$ screen using a Nogueira DPM-2 chopper (Irmãos Nogueira S.A. Máquinas Agrícolas e Motores, Itapira, São Paulo, Brazil). Monensin was provided with the mineral vitamin supplement, which contained $480 \mathrm{mg}$ of monensin per $\mathrm{kg}$ of product. The amount of monensina added was based in the monensina concentration in mineral vitamin supplement and in the amount normally used in practice by milk farmers. The same mineral vitamin supplement, but without monensin, was used for the treatment without ionophores. The 40HP pelletizer was utilized for the pelleting (Chavantes, Chavantes, SP, Brazil) located at the Iguatemi Experimental Farm, UEM, the ration's temperature checked of the end of process was around $95^{\circ} \mathrm{C}$ to $98^{\circ} \mathrm{C}$. The rations were balanced to provide isonitrogenous and isocaloric diets (Table 1) to meet Holstein dairy cows' requirements according to (NRC, 2001).

The pasture area consisted of four 0.4 ha paddocks with grasses of the Cynodon genus (Coast-cross, Tifton 85 and African star predominance). These grasses contained an average composition of $270.1 \pm 15 \mathrm{~g} / \mathrm{kg} \mathrm{DM}, 163.8 \pm 3 \mathrm{~g} / \mathrm{kg}$ $\mathrm{CP}, 22.1 \pm 3 \mathrm{~g} / \mathrm{kg}$ ether extract (EE), 664.8 $\pm 46 \mathrm{~g} / \mathrm{kg}$ neutral detergent fiber (NDF), $315 \pm 26 \mathrm{~g} / \mathrm{kg}$ acid detergent fiber (ADF), and $28.4 \pm 1.2 \mathrm{~g} / \mathrm{kg}$ lignin. The average precipitation was $175.4 \mathrm{~mm}$ during the trial, with an average temperature of $26^{\circ} \mathrm{C}$ (Maringá Main Climatological Station [ECPM] located at UEM).

The handling of the animals in the paddocks was determined by pasture height, such that the animals were placed in the paddocks when the grasses achieved an average height of $40 \mathrm{~cm}$ and they were removed from the paddocks when the grasses had an average height of $20 \mathrm{~cm}$. The sward height was measured at 10 different points in each paddock; pre-grazing heights were based on the length from soil level until the last leaf curvature, and the heights for post-grazing were measured on the length from soil level. In average the permanence of animals in each paddock was $2 \mathrm{~d}$.

\section{Experimental procedures}

The available forage mass was, on average, 1.7 ton $\mathrm{DM} / \mathrm{ha}$, and was estimated by using samples that were collected when the animals entered the paddocks, using a square $\left(1.0 \mathrm{~m}^{2}\right)$ in four points in each paddock from $5 \mathrm{~cm}$ of soil. For proximate composition, samples of the grazed stratum above the post grazing residue were manually 
Table 1. Ingredients of feed concentrates and chemical composition of total diets

\begin{tabular}{|c|c|c|c|c|}
\hline \multirow{2}{*}{ Items } & \multicolumn{2}{|c|}{ Non-pelleted } & \multicolumn{2}{|c|}{ Pelleted $^{1}$} \\
\hline & $\mathrm{CG}$ & CGM & CGP & CMP \\
\hline \multicolumn{5}{|l|}{ Ingredients } \\
\hline Ground maize ( $\mathrm{g} / \mathrm{kg}$ of DM) & 571.4 & 571.4 & 571.4 & 571.4 \\
\hline Soybean meal (g/kg of DM) & 54.3 & 54.3 & 54.3 & 54.3 \\
\hline Ground canola seeds ( $\mathrm{g} / \mathrm{kg}$ of $\mathrm{DM})$ & 285.7 & 285.7 & 285.7 & 285.7 \\
\hline Limestone $(\mathrm{g} / \mathrm{kg}$ of $\mathrm{DM})$ & 7.1 & 7.1 & 7.1 & 7.1 \\
\hline Calcium phosphate (g/kg of DM) & 11.4 & 11.4 & 11.4 & 11.4 \\
\hline Salt (g/kg of DM) & 0.6 & 0.6 & 0.6 & 0.6 \\
\hline Mineral and vitaminic suplement $(\mathrm{g} / \mathrm{kg} \text { of } \mathrm{DM})^{2}$ & 65.7 & 65.7 & 65.7 & 65.7 \\
\hline Sodium bicarbonate $(\mathrm{g} / \mathrm{kg}$ of $\mathrm{DM})$ & 3.7 & 3.7 & 3.7 & 3.7 \\
\hline Sodium monensin (mg/kg) & - & 31.54 & - & 31.54 \\
\hline \multicolumn{5}{|l|}{ Chemical composition of total diet } \\
\hline Dry matter $(\mathrm{g} / \mathrm{kg})$ & 557.9 & 559.1 & 557.5 & 558.2 \\
\hline Crude protein & 155.8 & 154.9 & 157.4 & 155.8 \\
\hline Ether extract & 72.9 & 74.6 & 67.4 & 67.4 \\
\hline Neutral detergent fiber & 431.8 & 434.4 & 432.2 & 434.3 \\
\hline Acid detergent fiber & 207.4 & 205.4 & 206.3 & 204.5 \\
\hline Non-fibrous carbohydrate & 273.6 & 266.2 & 274.1 & 276.3 \\
\hline
\end{tabular}

${ }^{1}$ CG, feed concentrate with ground canola seeds; CGM, feed concentrate CG with sodium monensin addition; CGP, feed concentrate CG pelleted; CMP, feed concentrate $\mathrm{CG}$ with sodium monensin addition and pelleted.

${ }^{2} \mathrm{Ca}, 156 \mathrm{~g} / \mathrm{kg} ; \mathrm{P}, 51 \mathrm{~g} / \mathrm{kg} ; \mathrm{S}, 20 \mathrm{~g} / \mathrm{kg} ; \mathrm{Na}, 93 \mathrm{~g} / \mathrm{kg} ; \mathrm{K}, 28 \mathrm{~g} / \mathrm{kg} ; \mathrm{Mg}, 33 \mathrm{~g} / \mathrm{kg} ; \mathrm{Fe}, 2,000 \mathrm{mg} / \mathrm{kg} ; \mathrm{Cu}, 400 \mathrm{mg} / \mathrm{kg} ; \mathrm{Co}, 30 \mathrm{mg} / \mathrm{kg} ; \mathrm{Cr}, 10 \mathrm{mg} / \mathrm{kg} ; \mathrm{I}, 40 \mathrm{mg} / \mathrm{kg}$; Se, 15 mg/kg; Zn, 1,700 mg/kg; F, maximum 510 mg/kg; Mn, 1,350 mg/kg; Vit. A, 135,000 UI/kg; Vit. D, 68,000 UI/kg; Vit. E, 450 mg/kg.

collected from several points in each paddock. Samples of pasture were pooled based on period and paddock to obtain one sample/period.

To determine the dry matter intake (DMI) and nutrient intake of the concentrate, the amount of concentrate offered was recorded daily such as orts. Concentrate intake was adjusted daily until the beginning of the collection week, and it was limited based on the estimated intake of $3.0 \%$ body weight, while a roughage:concentrate ratio of $60: 40$ was offered. During the collection periods, concentrate and orts were sampled daily. At the end of each experimental period, a sample pool was performed, thereby resulting in a unique sample per animal per period. Roughage intake was estimated using the indigestible dry matter (iDM) as an internal marker, and was estimated in the samples of concentrate, orts and feces. To estimate the daily fecal excretion, we utilized chromium oxide $\left(\mathrm{Cr}_{2} \mathrm{O}_{3}\right)$ as an external marker, which was provided orally in cellulose bags from the 5 th to 15 th day of each experimental period. Chromium oxide was given twice daily (5 g each), thus totaling $10 \mathrm{~g}$ of external marker per animal per day (Detmann et al., 2001). For the apparent digestibility assay, fecal samples were collected directly from the rectum from the 10th to 15 th day of the experimental period, twice daily (8:00 $\mathrm{h}$ and 16:00 h), and a composed sample was proportionally performed on a dry weight basis per animal/period for further analyses.

Milk production was recorded daily and corrected for $3.5 \%$ fat content of milk. Milk was sampled on the 17 th and 18th day of each experimental period, and a composite sample was proportionally performed in relation to the milk production in the morning and in the afternoon. The sample was then stored in a plastic bottle with the preservative 2bromo 2-nitropropano 1-3-diol (bromopol), for the analyses of dry extract, $\mathrm{CP}$, fat, somatic cell count (SCC), and urea. A portion of the composite sample was stored in a plastic bottle and frozen at $-20^{\circ} \mathrm{C}$ for lipid composition analysis. Also, measurements of milk acidity and density were performed.

For the butter fabrication, 10 liters of milk from each animal were collected in a ratio that was proprotional to the milk production in the morning and in the afternoon. The milk was kept at $4{ }^{\circ} \mathrm{C}$ for 2 days for the precipitation of fat, which was removed and stored in plastic bottles at $-10^{\circ} \mathrm{C}$ over one day. After this period, the fat was processed in a mixer to obtain the butter, which was then stored in plastic bottles under refrigerated conditions for further analyses.

\section{Laboratory analyses}

Samples of roughage, concentrate, orts, and feces were dried in a forced oven at $55^{\circ} \mathrm{C}$ for 72 hours and ground in a mill with a 1-mm screen to determine DM, CP, EE (AOAC, 1990), NDF, ADF, and lignin (Van Soest et al., 1991). Nonfibrous carbohydrates were calculated according to Hall (2000) while total digestible nutrients were calculated according to the equation proposed by Weiss et al. (1992). For analysis of iDM in samples from concentrate, orts, and fecal composite samples, an in situ digestibility procedure 
was used over the course of $240 \mathrm{~h}$, based on information from Cochran et al. (1986) and Casali et al. (2008). Estimates of fecal excretion were obtained for the equation proposed by Smith and Reid (1955). The determination of the chromium concentration was performed as described by the methodology of Willians et al. (1962).

Chemical composition of milk were determined through the Bentley-2000 infrared analyzer and SCC was determined by the Somacount-500. To determine the values of milk acidity and density, the Dornik solution and thermolactodensimeter were used, respectively (AOAC, 1984). For the determination of methyl esters of FA in milk fat, the milk fat was extracted by centrifugation $(17.800 \times \mathrm{g})$. The transesterification of triglycerides to obtain FA methyl esters was performed according to the 5509 method of ISO (1978), in n-heptane and KOH/methanol solution. The FA methyl esters were analyzed by gas chromatography TraceGC Ultra (Thermo Scientific, Tewksbury, MA, USA) equipped with an automatic sampler, flame ionization detector, and a fused silica capillary column (100 m long, $0.25 \mathrm{~mm}$ internal diameter, and $0.20 \mu \mathrm{m}$ - Restek Rt-2560 phase $100 \%$ bicianopropil polysiloxane). The gas output was $1.4 \mathrm{~mL} / \mathrm{min}$, the flow for the carrier gas $\left(\mathrm{H}_{2}\right)$ and for the auxiliary gas $\left(\mathrm{N}_{2}\right)$ were $35 \mathrm{~mL} /$ minute, and $350 \mathrm{~mL} / \mathrm{min}$ for synthetic air. The initial temperature of the column was $65^{\circ} \mathrm{C}$ for 4 minutes, after which it was raised at a rate of $16^{\circ} \mathrm{C} /$ minute up to $185^{\circ} \mathrm{C}$; this lasted for $12 \mathrm{~min}$, then at a rate of $20^{\circ} \mathrm{C} / \mathrm{min}$, the final temperature of $285^{\circ} \mathrm{C}$ was reached and maintained for $14 \mathrm{~min}$. The injection volume was 1 microliter and the sample split ratio was 1:100. The peaks were identified through comparisons with the retention times of the standard FA methyl esters (Sigma, St. Louis, MO, USA).

Analyses of butter texture (firmness and adhesiveness) were performed in samples stored at $4^{\circ} \mathrm{C}$ by using the texture measurer TAXT plus Texture Analyzer (Stable Micro Systems, London, UK) with a conical probe of $45^{\circ}$. The probe penetrated $23 \mathrm{~mm}$ into the sample surface at a speed of $3 \mathrm{~mm} / \mathrm{s}$; the penetration force applied on the sample indicated the firmness of the butter, and the negative force applied to withdraw the probe indicated the sample's tackiness stickiness.

\section{Statistical analyses}

Statistical analyses were performed using the PROC MIXED procedure (SAS Institute, Inc, 2011) with a $2 \times 2$ factorial arrangement. The statistic model was as follows: $\mathrm{Y}_{i j k}=\mu+\mathrm{T}_{i}+\mathrm{P}_{j}+\mathrm{A}_{k}+\mathrm{e}_{i j k}$, where $\mathrm{Y}_{i j k}=$ observation of $k$ replication for $i$ treatment in the $j$ period; $\mu=$ general mean; $\mathrm{T}_{i}=i$ treatment effect (CG, CGM, CGP, and CMP); $\mathrm{P}_{j}=j$ period effect $\left(1,2,3\right.$, and 4); $\mathrm{A}_{k}=$ animal effect $(1,2,3$, and 4); and $\mathrm{e}_{i j k}=$ random error associated with animal $k$ receiving treatment $i$ in the period $j$. Treatments were compared to provide factorial contrasts: pelleted vs non pelleted, with monensin versus without monensin, and the interaction between pelleting and monensin. When an interaction was observed, the means were compared using the Scheffe Test. We considered $5 \%(p<0.05)$ to be the significance level, and up to $10 \%(\mathrm{p}<0.10)$ as a tendency.

\section{RESULTS}

The DMI of total diet (roughage and concentrate; $\mathrm{kg} / \mathrm{d}$ ) was $12.7 \pm 0.83 \mathrm{~kg} / \mathrm{d}$ (Table 2); being $5.4 \pm 0.6 \mathrm{~kg}$ was from the concentrate, and $7.8 \pm 0.6 \mathrm{~kg}$ was from the roughage (data not shown). The roughage:concentrate ratio during all experimental periods was 57:43. Considering the amount of monensin added to the concentrate $(31.5 \mathrm{mg} / \mathrm{kg} \mathrm{DM})$ and the DMI of concentrate, the daily monensin intake was $169.7 \mathrm{mg} /$ animal. At this amount, monensin did not alter the nutrient intake. However, EE intake was reduced by the pelleting $(\mathrm{p}<0.05)$

We did not observe an interaction between the use of pelleting and the addition of monensin on apparent nutrient digestibility (Table 2). The digestibility was also not influenced by treatment singly, except for apparent ADF digestibility $(\mathrm{p}<0.05)$, where pelleting decreased the digestibility by $11.0 \%$.

Milk production and composition were not altered by the addition of monensin or the pelleting. Also, interaction was not observed between the pelleting and the addition of monensin (Table 3). We did not observe treatment interactions on the concentration of PUFA, monounsaturated fatty acids (MUFA), SFA, omega 6, and omega 3 in the milk or for PUFA/SFA and omega 6/omega 3 ratios (Table 4). The pelleting increased MUFA concentration in the milk by $7.4 \%(\mathrm{p}<0.05)$ and decreased SFA concentration from $54.4 \mathrm{~g} / 100 \mathrm{~g}$ to $51.0 \mathrm{~g} / 100 \mathrm{~g}$ FA, which corresponds with a reduction of $6.1 \%(\mathrm{p}<0.05)$; also, the PUFA/SFA ratio $(\mathrm{p}<0.05)$ increased and omega 6/omega 3 FA ratios were also increased by $29.5 \%$. Compared to treatments without monensin, the addition of monensin increased PUFA concentration in the milk by $15.3 \%$ $(\mathrm{p}<0.05)$ and increased omega 6 concentration by $13.0 \%$. Also, the PUFA/SFA ratio ( $\mathrm{p}<0.05$ ) was increased by $21.0 \%$. Saturated fatty acid concentration tended to decrease with the addition of monensin $(\mathrm{p}<0.10)$.

Considering FA concentration individually (Table 4), there was an interaction $(\mathrm{p}<0.05)$ between the pelleting and the addition of monensin on C6:0, C8:0, C17:0, C17:1, C20:1, and CLA (C18:2 c9 t11) concentrations; the combination of treatments increased the concentration of CLA by $46.9 \%$ in the milk when compared to the control treatment. The concentrations of $\mathrm{C} 8: 0$ and $\mathrm{C} 20: 1$ were greater with the addition of monensin, while the concentrations of $\mathrm{C} 17: 0$ and $\mathrm{C} 17: 1$ were greater with the 
Table 2. Nutrient intake (concentrate+pasture) and whole diet (concentrate+pasture) total tract apparent digestibility (TTAD) of Holstein cows grazing on Cynodon pasture and supplemented with pelleted or non-pelleted concentrate containing canola seed and with or without monensin addition

\begin{tabular}{|c|c|c|c|c|c|c|c|c|}
\hline \multirow{2}{*}{ Items } & \multicolumn{2}{|c|}{ Non-pelleted } & \multicolumn{2}{|c|}{ Pelleted $^{1}$} & \multirow{2}{*}{ SE } & \multicolumn{3}{|c|}{ Probability $^{2}$} \\
\hline & CG & CGM & CGP & CMP & & $\mathrm{M}$ & $\mathrm{P}$ & I \\
\hline \multicolumn{9}{|l|}{ Intake $(\mathrm{kg} / \mathrm{d})$} \\
\hline $\mathrm{DM}$ & 13.42 & 13.02 & 12.90 & 11.51 & 0.84 & 0.31 & 0.25 & 0.57 \\
\hline $\mathrm{CP}$ & 2.11 & 2.03 & 2.06 & 1.84 & 0.14 & 0.30 & 0.40 & 0.63 \\
\hline $\mathrm{EE}$ & 1.05 & 1.06 & 0.80 & 0.83 & 0.06 & 0.74 & 0.03 & 0.82 \\
\hline NDF & 5.76 & 5.60 & 6.10 & 4.95 & 0.46 & 0.19 & 0.75 & 0.31 \\
\hline $\mathrm{ADF}$ & 2.77 & 2.72 & 2.91 & 2.32 & 0.22 & 0.19 & 0.56 & 0.26 \\
\hline $\mathrm{NFC}^{3}$ & 3.86 & 3.65 & 3.24 & 3.31 & 0.29 & 0.82 & 0.13 & 0.65 \\
\hline \multicolumn{9}{|l|}{ TTAD $(\mathrm{g} / \mathrm{kg})$} \\
\hline $\mathrm{DM}$ & 616.5 & 606.7 & 619.4 & 614.1 & 0.79 & 0.36 & 0.53 & 0.78 \\
\hline $\mathrm{CP}$ & 666.3 & 670.0 & 699.4 & 669.6 & 1.09 & 0.27 & 0.17 & 0.15 \\
\hline $\mathrm{EE}$ & 873.8 & 882.5 & 886.9 & 909.2 & 1.15 & 0.21 & 0.12 & 0.57 \\
\hline $\mathrm{NDF}$ & 485.8 & 472.8 & 491.9 & 460.8 & 1.89 & 0.27 & 0.88 & 0.64 \\
\hline $\mathrm{ADF}$ & 422.0 & 396.3 & 368.3 & 359.2 & 1.94 & 0.39 & 0.04 & 0.68 \\
\hline NFC & 782.3 & 751.9 & 789.3 & 769.1 & 2.68 & 0.37 & 0.66 & 0.85 \\
\hline $\mathrm{TDN}(\mathrm{g} / \mathrm{kg})^{3}$ & 698.0 & 685.5 & 673.3 & 678.9 & 1.11 & 0.76 & 0.19 & 0.44 \\
\hline
\end{tabular}

SE, standard error; DM, Dry matter; CP, Crude protein; EE, Ether extract; NDF, Neutral detergent fiber; ADF, Acid detergent fiber; NFC, non fibrous carbohydrates; TDN, total digestive nutrients.

${ }^{1}$ CG, feed concentrate with ground canola seeds; CGM, feed concentrate CG with sodium monensin addition; CGP, feed concentrate CG pelleted; CMP, feed concentrate CG with sodium monensin addition and pelleted.

${ }^{2} \mathrm{M}$, monensin effect; $\mathrm{P}$, pelleted effect; I, interaction effect.

${ }^{3} \mathrm{NFC}=100-(\mathrm{CP} \%+(\mathrm{NDF} \%-\mathrm{NDFcp})+\mathrm{EE} \%+\mathrm{MM} \%)($ Hall, 2000); TDN = CPD\%+NDFD\%+NFCD\%+(EED\% 2.25$)\left(\right.$ Weiss et al.,1992), were NDF $\mathrm{cp}_{\mathrm{p}}$, neutral detergent fiber corrected for crude protein; MM, mineral matter; CPD, crude protein digestible; NDFD, Neutral detergent fiber digestible; NFCD, non fibrous carbohydrates digestible; EED, ether extract digestible.

pelleting treatment. There was an effect of monensin ( $\mathrm{p}<0.05$ ) on $\mathrm{C} 4: 0$ and $\mathrm{C} 18: 0$ concentrations, as they were reduced by the addition of monensin by $18.0 \%$ and $9.2 \%$, respectively; meanwhile, the concentrations of $\mathrm{C} 16: 1 \mathrm{n}-7$, C18:2 n-6, and C20:3 n-6 were increased. The pelleting decreased $(\mathrm{p}<0.05)$ the concentrations of $\mathrm{C} 10: 0, \mathrm{C} 14: 0$, and C18:0 by $28.0 \%, 13.5 \%$, and $15.0 \%$, respectively; however, the pelleting increased the concentrations of C16:1 n-7, C16:1 n-9, and C18:1 n-9. Although PUFA concentration increased and SFA concentration decreased in the milk with the addition of monensin and the pelleting; the treatments did not influence the texture of the butter (Table 5).

\section{DISCUSSION}

The results of the influence of monensin on DMI are quite varied, thus showing that they are different according to the amount of monensin supplied and among cows

Table 3. Production and milk composition of Holstein cows grazing on Cynodon pasture and supplemented with pelleted or non-pelleted concentrate containing canola seed and with or without monensin addition

\begin{tabular}{|c|c|c|c|c|c|c|c|c|}
\hline \multirow{2}{*}{ Items } & \multicolumn{2}{|c|}{ No-pelleted } & \multicolumn{2}{|c|}{ Pelleted $^{1}$} & \multirow{2}{*}{ SE } & \multicolumn{3}{|c|}{ Probability $^{2}$} \\
\hline & CG & CGM & CGP & CMP & & $\mathrm{P}$ & M & I \\
\hline Milk production $(\mathrm{kg} / \mathrm{d})$ & 16.36 & 14.12 & 13.12 & 15.27 & 1.4 & 0.48 & 0.97 & 0.15 \\
\hline Fat $(\mathrm{g} / \mathrm{kg})$ & 38.5 & 34.7 & 31.3 & 32.6 & 0.26 & 0.11 & 0.64 & 0.35 \\
\hline Protein $(\mathrm{g} / \mathrm{kg})$ & 29.7 & 28.7 & 31.1 & 28.8 & 0.15 & 0.62 & 0.32 & 0.68 \\
\hline Lactose $(\mathrm{g} / \mathrm{kg})$ & 42.1 & 44.6 & 44.1 & 4.30 & 0.11 & 0.85 & 0.56 & 0.13 \\
\hline Total solids (g/kg) & 118.5 & 115.8 & 115.0 & 112.4 & 0.23 & 0.17 & 0.28 & 0.99 \\
\hline $\operatorname{SCC}\left(\log _{10}\right)$ & 2.13 & 2.00 & 2.23 & 2.19 & 0.24 & 0.56 & 0.75 & 0.84 \\
\hline Urea-N (mg/dL) & 13.14 & 12.39 & 12.53 & 13.09 & 0.90 & 0.96 & 0.92 & 0.49 \\
\hline Acidity $\left({ }^{\circ} \mathrm{D}\right)$ & 19.6 & 19.7 & 19.2 & 18.9 & 0.05 & 0.26 & 0.83 & 0.72 \\
\hline Density (g/L) & 1,027 & 1,027 & 1,027 & 1027 & 0.73 & 0.90 & 0.85 & 0.91 \\
\hline
\end{tabular}

SE, standard error; SCC, somatic cell count.

${ }^{1} \mathrm{CG}$, feed concentrate with ground canola seeds; CGM, feed concentrate CG with sodium monensin addition; CGP, feed concentrate CG pelleted, CMP, feed concentrate $C G$ with sodium monensin addition and pelleted.

${ }^{2} \mathrm{P}$, pelleted effect; $\mathrm{M}$, monensin effect; I, interaction effect. 
Table 4. Lipid composition ( $\mathrm{g} / 100 \mathrm{~g}$ of fatty acids) of milk of Holstein cows grazing on Cynodon pasture and supplemented with pelleted or non-pelleted concentrate containing canola seed and with or without monensin addition

\begin{tabular}{|c|c|c|c|c|c|c|c|c|}
\hline \multirow{2}{*}{ Fatty acids } & \multicolumn{2}{|c|}{ No-pelleted } & \multicolumn{2}{|c|}{ Pelleted $^{1}$} & \multirow{2}{*}{ SE } & \multicolumn{3}{|c|}{ Probability $^{2}$} \\
\hline & $\mathrm{CG}$ & CGM & CGP & CMP & & $\mathrm{M}$ & $\mathrm{P}$ & $\mathrm{I}$ \\
\hline C4:0 & 0.79 & 0.72 & 0.79 & 0.57 & 0.06 & 0.04 & 0.26 & 0.30 \\
\hline C6:0 & 0.75 & 0.8 & 0.51 & 1.87 & 0.14 & $<0.01$ & 0.02 & $<0.01$ \\
\hline C8:0 & 0.30 & 0.59 & 0.50 & 0.39 & 0.08 & 0.29 & 1.00 & 0.04 \\
\hline C10:0 & 1.04 & 1.15 & 0.61 & 0.95 & 0.12 & 0.09 & 0.03 & 0.38 \\
\hline C12:0 & 1.21 & 1.16 & 1.04 & 1.10 & 0.14 & 0.95 & 0.43 & 0.70 \\
\hline C13:0 & 1.37 & 1.34 & 0.94 & 1.38 & 0.14 & 0.18 & 0.19 & 0.12 \\
\hline C14:0 & 5.05 & 5.28 & 4.37 & 4.63 & 0.28 & 0.39 & 0.04 & 0.95 \\
\hline C14:1n5 & 0.31 & 0.32 & 0.31 & 0.31 & 0.02 & 0.71 & 0.88 & 0.99 \\
\hline $\mathrm{C} 14: 1 \mathrm{n} 7$ & 0.45 & 0.47 & 0.42 & 0.50 & 0.03 & 0.16 & 0.97 & 0.51 \\
\hline C15:0 & 0.67 & 0.81 & 0.73 & 0.83 & 0.09 & 0.21 & 0.61 & 0.81 \\
\hline C16:0 & 18.13 & 18.35 & 20.03 & 18.47 & 0.49 & 0.21 & 0.07 & 0.10 \\
\hline C16:1n7 & 0.16 & 0.18 & 0.17 & 0.27 & 0.02 & 0.03 & 0.05 & 0.13 \\
\hline $\mathrm{C} 16: \ln 9$ & 0.51 & 0.58 & 0.66 & 0.69 & 0.03 & 0.12 & $<0.01$ & 0.54 \\
\hline C17:0 & 0.59 & 0.60 & 0.76 & 0.59 & 0.02 & $<0.01$ & $<0.01$ & $<0.01$ \\
\hline C17:1 & 0.38 & 0.32 & 0.64 & 0.33 & 0.02 & $<0.01$ & $<0.01$ & $<0.01$ \\
\hline C18:0 & 23.93 & 22.62 & 21.24 & 18.41 & 0.66 & 0.01 & $<0.01$ & 0.28 \\
\hline C18:1n9 & 38.45 & 38.10 & 40.31 & 41.59 & 0.51 & 0.39 & $<0.01$ & 0.15 \\
\hline $\mathrm{C} 18: 2 \mathrm{c} 9 \operatorname{tr} 11$ & 0.96 & 0.90 & 0.86 & 1.41 & 0.13 & 0.09 & 0.14 & 0.04 \\
\hline C18:2n6 & 3.31 & 3.79 & 3.65 & 4.04 & 0.18 & 0.04 & 0.15 & 0.79 \\
\hline C18:3n3 & 0.47 & 0.48 & 0.36 & 0.46 & 0.06 & 0.34 & 0.28 & 0.44 \\
\hline C20:0 & 0.43 & 0.55 & 0.32 & 0.49 & 0.08 & 0.09 & 0.30 & 0.74 \\
\hline C20:1 & 0.16 & 0.20 & 0.18 & 0.16 & 0.01 & 0.45 & 0.50 & 0.04 \\
\hline C20:3n6 & 0.04 & 0.10 & 0.09 & 0.12 & 0.02 & 0.05 & 0.13 & 0.57 \\
\hline C20:4n6 & 0.15 & 0.15 & 0.14 & 0.13 & 0.01 & 0.68 & 0.19 & 0.89 \\
\hline $\mathrm{C} 22: 2$ & 0.13 & 0.16 & 0.14 & 0.13 & 0.02 & 0.58 & 0.64 & 0.22 \\
\hline $\mathrm{C} 23: 0$ & 0.26 & 0.22 & 0.23 & 0.18 & 0.04 & 0.23 & 0.35 & 0.87 \\
\hline PUFA & 5.06 & 5.58 & 5.24 & 6.29 & 0.24 & 0.01 & 0.10 & 0.32 \\
\hline MUFA & 40.42 & 40.17 & 42.69 & 43.85 & 0.51 & 0.40 & $<0.01$ & 0.20 \\
\hline SFA & 54.52 & 54.25 & 52.07 & 49.86 & 0.64 & 0.09 & $<0.01$ & 0.17 \\
\hline Omega 6 & 3.50 & 4.04 & 3.88 & 4.29 & 0.18 & 0.03 & 0.12 & 0.72 \\
\hline Omega 3 & 0.47 & 0.48 & 0.36 & 0.46 & 0.06 & 0.34 & 0.28 & 0.44 \\
\hline PUFA/SFA & 0.09 & 0.10 & 0.10 & 0.13 & 0.006 & 0.01 & 0.02 & 0.21 \\
\hline Omega 6/omega 3 & 7.58 & 8.58 & 10.85 & 10.06 & 1.03 & 0.92 & 0.05 & 0.41 \\
\hline
\end{tabular}

SE, standard error; PUFA, polyunsaturated fatty acids; MUFA, monounsaturated fatty acids; SFA, saturated fatty acids.

${ }^{1}$ CG, feed concentrate with ground canola seeds; CGM, feed concentrate CG with sodium monensin addition; CGP, feed concentrate CG pelleted; CMP, feed concentrate $\mathrm{CG}$ with sodium monensin addition and pelleted.

${ }^{2} \mathrm{M}$, monensin effect; P, pelleted effect; I, interaction effect.

confined, on pasture or receiving diets high in roughage DMI in dairy cows can be mediated by an increase in (Ruiz et al., 2001; Ipharraguerre and Clark, 2003; Gandra et propionate concentration in the rumen, which would meet al., 2010). The mode of action of monensin in reducing the glucose demand of the mammary gland by

Table 5. Butter texture of milk produced by cows grazing on pasture and supplemented with pelleted concentrate or not, with or without addition of monensin butter

\begin{tabular}{|c|c|c|c|c|c|c|c|c|}
\hline \multirow{2}{*}{ Texture (g) } & \multicolumn{2}{|c|}{ No-pelleted } & \multicolumn{2}{|c|}{ Pelleted $^{1}$} & \multirow{2}{*}{ SE } & \multicolumn{3}{|c|}{ Probability $^{2}$} \\
\hline & $\mathrm{CG}$ & CGM & CGP & CMP & & $\mathrm{M}$ & $P$ & I \\
\hline Adhesiveness & -7.408 & -7.170 & -7.199 & -6.880 & 0.86 & 0.75 & 0.78 & 0.96 \\
\hline Firmness & 37.202 & 44.383 & 40.442 & 39.401 & 3.06 & 0.34 & 0.78 & 0.21 \\
\hline
\end{tabular}

SE, standard error.

${ }^{1} \mathrm{CG}$, feed concentrate with ground canola seeds; CGM, feed concentrate CG with sodium monensin addition; CGP, feed concentrate CG pelleted; CMP, feed concentrate $\mathrm{CG}$ with sodium monensin addition and pelleted.

${ }^{2} \mathrm{M}$, monensin effect; P, pelleted effect; I, interaction effect. 
gluconeogenesis. Thus, when the demand for glucose by the body is reduced, the excess propionate can be oxidized in the liver by reducing starvation (Oba and Allen, 2003). Grazing cattle or those feeding high amounts of roughage increases the difficulty of meeting the energy demand (NRC, 2001). When monensin is added to the diet of grazing animals, the greater propionate production and reduced methane production yield more energy to the animal without affecting consumption (Ipharraguerre and Clark, 2003). Reduction in EE consumption using pelleting can be explained by how the pelleting reduces the EE content in the concentrate (data not show) and in the total diets (Table 1). It is common to have oil loss during the thermal processing of foods (Riaz, 2000) and what leads us to consider this hypothesis is that we performed only one mixture of the ration, which a portion of this mixture was pelleted and another not, thereby constituting the treatment CGP and CG, respectively. Therefore, the CGP and CG treatments had the same composition, with the heat treatment as the only difference between them. A reduction in $\mathrm{EE}$ intake in the total diet was also observed by dos Santos et al. (2011) that worked wich ground sunflower seeds in a pelleted vs non-pelleted concentrate treated with or without lignosulfonate.

The pelleting reduced the ADF contents of the concentrate (data not show), as well as reducing the intake of these nutrients. This effect also was observed in the fiber digestibility (Table 2). One hypothesis would be the negative interference from high levels of $\mathrm{EE}$ in the samples during the measurement by gravimetric difference of the fiber, because the EE affects the filter process, and in some situations, promotes the obstruction of the equipment due to an excess of fat in the sample (AOAC, 1997). Except for the lower apparent digestibility of ADF by the pelleting, our results agree with other studies in which the canola seeds thermally protected did not affect the digestibility of nutrients (Neves et al., 2009). Moreover, similar results were observed by Neves et al. (2007), where the authors observed a reduction in digestibility of NDF and ADF in diets that were thermally treated.

The increase in the hepatic flow of gluconeogenesis precursors caused by the addition of monensin can promote an average increase of $2 \%$ in the milk production of dairy cows (Duffield et al., 2008). In the present study, monensin was given to the primiparous cows over the course of 135 days of lactation. The monensin concentration in the diet was $31.5 \mathrm{~g} / \mathrm{kg}$ (intake of $169.7 \mathrm{mg} / \mathrm{d}$ ), which was much less than that provided in other experiments (above $320 \mathrm{mg}$ monensin/d) where the production or milk composition, mainly fat, were altered. The differences between the results of some studies also are influenced by the stage of lactation and feeding (Ruiz et al., 2001; da Silva et al., 2007). In grazing animals or those fed high roughage levels, the major beneficial effect of monensin is the greater production of propionic acid vs methane production and acetic acid, thereby resulting in an improved energy efficiency due to the inhibitory effect of monensin on cellulolytic gram-positive bacterias, and a consequent increase in milk production and leading to milk fat depression (Duffield et al., 2008). Monensin has shown a greater benefit in the performance of grazing cattle, or cattle on diets containing high levels of roughage, than diets with high concentrate levels (Lana and Russell, 2001). Although the animals in the present study were kept on pasture, monensin did not alter the production and milk composition. One factor that could have prevented the effect of monensin in this study was the addition of sodium bicarbonate to the concentrate, because it is a buffering agent that increases the proportion of acetate/propionate in the rumen; in other words, it has the opposite effect of monensin (Nagajara et al., 1997). Another issue is the number of animals used in the present work that can has contributed with the results.

In the recent past of human nutrition, some fatty acids, mainly the lauric acid (C12:0), myristic (C14:0), and palmitic acid (C16:0) were considered to be atherogenic (Mensink et al., 2003). In these sense, the results observed in this study were positive for myristic acid in pelleted treatments, since pelleting reduced $(\mathrm{p}<0.05)$ the content of this fatty acid in milk by $13.5 \%$. Despite of the tendency to increased levels of palmitic acid $(p<0.10)$ in pelleted treatments, studies in rats show that palmitic acid has reduced atherogenic effects when consumed along with adequate levels of unsaturated FA as linoleic acid or omega6 (1/3 of total fatty acids, Clandinin et al., 2000; Fernandez and Webb, 2008), this fatty acid is in canola, and its concentration increased in milk with the addition of monensin (Table 3). Indeed, recent meta-analysis showed that there is no significant evidence for concluding that dietary saturated fat is associated with an increased risk of coronary heart disease or cardiovascular disease (Schwingshackl and Hofmann, 2014).

The analysis of 10 experiments using monensin showed a decrease in the synthesis of short and medium chains of FA and of stearic acid (C18:0), but an increase in the synthesis of long chain FA such as CLA (Duffield et al., 2008). Similar results were observed in the present study, where monensin decreased $\mathrm{C} 18: 0$ by $9.2 \%$ and tended to increase the CLA content by $26.9 \%$. Besides monensin, the pelleting also reduced the concentration of $\mathrm{C} 18: 0$ by $15.0 \%$ (23.28 for non-pelleted vs $19.83 \mathrm{~g} / 100 \mathrm{~g}$ of FA for pelleted concentrates), thus agreeing with dos Santos et al. (2011). The reduced concentration of C18:0 may indicate a decrease in the ruminal biohydrogenation process (final product of ruminal biohydrogenation) and that more intermediary products, such as the C18:1 trans-11 (vaccenic acid), were retained in the rumen and subsequently 
converted to CLA by the delta-9-desaturase in the mammary gland.

Both the pelleting and monensin promoted an increase in palmitoleic acid (C16:1 n-7) production, and although numerically higher, the pelleting and monensin had no interaction effect. The palmitoleic acid is a fatty acid omega-7, which is abundant in plants; also, it is biosynthesized from palmitic acid (C16:0) by the action of the enzyme delta-9 desaturase (Yang et al., 2011). Recent studies in mice and humans show that the fatty acid C16:1n7 improves blood lipid composition and increases insulin sensitivity by inhibiting apoptosis of pancreatic beta cells (Yang et al., 2011). In the present study there was no influence of treatments on blood parameters in the animals (unpublish data).

The pelleting was effective in protecting the oleic acid (C18:1 n-9), thereby increasing its concentration in milk by $6.9 \%$. The C18:1 n-9 occurs naturally in the fat from animals and vegetables; in canola it represents $53 \%$ to $70 \%$ of FA (ANVISA, 1999). The literature does not mention C18:1 n-9 as one of the intermediates of fatty acid biohydrogenation of C18:2 c9 c12 (linoleic acid - omega 6) and C18:3 c9 c12 c15 ( $\alpha$-linolenic acid, omega 3; Shingfield et al., 2010). The use of PUFA sources and heat treatment, such as extrusion, led to an increased CLA concentration (Akraim et al., 2007). In this study, the pelleting alone did not occur, probably due to the fact that the temperature in the pelleting was lower than in the extrusion process. However, the pelleting combined with monensin were effective in increasing the CLA levels by $46.9 \%$ ( $\mathrm{p}<0.05)$. This result corroborates with some studies that reported an increase in CLA concentration in diets that were thermally treated or contained added monensin (Neves et al., 2009; da Silva-Kazama et al., 2011).

The omega 3 and 6 FA compete in the organism through metabolism by the enzyme delta-6-desaturase metabolism. Thus, the imbalance in the ratio of these FA contributes to the occurrence of diseases such as cancer, Alzheimer's, obesity, and inflammatory processes, such that omega-6 increases the inflammatory processes while omega 3 decreases them (Petit, 2010). While a ratio of omega6/omega-3 of 10 to 5:1 may be considered satisfactory (Nutrition and Health Collection 1999; Institute of Medicine, 2002), the most recent proposal, based on animal experiments, is 1:1 (Fürst, 2002). In this study, the average ratio (10.5 g/100 $\mathrm{g}$ of FA) was above the recomended ratio.

The SFA content in milk is strongly correlated with the firmness of butter (Hurtaud et al., 2010). Differences in the firmness of butter occur, for example, when there is a change in the pastures grazed during summer versus silage intake during winter, which is directly related to the change in fatty acid composition of milk fat (Couvreur et al., 2006).
Considering that the process of butter production does not alter the fatty acid composition (da Silva-Kazama et al., 2010; Hurtaud et al., 2010; Oeffner et al., 2013), we expected an improvement of the butter texture and spreadability. However, the changes in the fatty acid profile were not sufficient to yield those improvements.

\section{CONCLUSION}

Supplying monensin to cows kept on pasture and supplementing them with concentrate containing ground canola seeds does not alter the intake and digestibility. Pelleting reduces EE and $\mathrm{ADF}$ intake, and also reduces the ADF digestibility of concentrates containing canola seeds. The association of pelleting with monensin does not alter the production, milk composition, and butter texture. However, it alters the lipid composition of milk. Pelleting increases the omega 6:omega 3 ratio of milk, and the pelleting associated with monensin increases the CLA concentration in milk.

\section{ACKNOWLEDGMENTS}

The present study was funded by Coordenação de Aperfeiçoamento de Pessoal de Nível Superior (CAPES) and Conselho Nacional de Desenvolvimento Científico e Tecnológico (CNPq-Brazil) from Brazil. Special thanks to Associação Paranaense dos Criadores de Bovinos da Raça Holandesa (APCBRH).

\section{REFERENCES}

Akraim, F., M. C. Nicot, P. Juaneda, and F. Enjalbert. 2007. Conjugated linolenic acid (CLnA), conjugated linoleic acid (CLA) and other biohydrogenation intermediates in plasma and milk fat of cows fed raw or extruded linseed. Animal 1:835-843.

ANVISA. 1999. Technical regulation for fixing identity and quality of oils and vegetable fats. Resolution $\mathrm{n}^{\circ} 482$, September 23, 1999. National Health Surveillance Agency, Brasilia, DF, Brazil.

AOAC. 1984. Official Methods of Analysis. 14th edn. Association of Official Analytical Chemists, Washington, DC, USA.

AOAC. 1990. Official Methods of Analysis. 15th edn. Association of Official Analytical Chemists. Washington, DC, USA.

AOAC. 1997. Official Methods of Analysis. 16th edn. Association of Official Analytical Chemists. Arlington, VA, USA.

Bizac, B. L. and P. Sanders. 2015. Monensin. Food and Agriculture Organization of the United Nations. ftp://ftp.fao.org/ag/agn/jecfa/vetdrug/12-2012-monensin.pdf. Accessed January 20, 2015.

Casali, A. O., E. Detmann, S. d. C. V. Filho, J. C. Pereira, L. T. Henriques, S. G. d. Freitas, and M. F. Paulino. 2008. Influence of incubation time and particles size on indigestible 
compounds contents in cattle feeds and feces obtained by in situ procedures. Rev. Bras. Zootecn. 37:335-342.

Canola Council of Canada. 2015. Canola oil physical and chemical properties. Roman Przybylski. http://www. canolacouncil.org/media/515239/canola_oil_physical_chemica 1_properties_1.pdf. Accessed January 20, 2015.

Cichosz, G. and H. Czeczot. 2012. Milk fat in prophylaxis of cancer diseases. Pol. Merkur. Lekarski. 33:168-172.

Clandinin, M. T., S. L. Cook, S. D. Konard, M. A. French. 2000. The effect of palmitic acid on lipoprotein cholesterol levels. Int. J. Food Sci. Nutr. 51:S61-S71.

Cochran, R. C., D. C. Adams, J. D. Wallace, M. L. Galyean. 1986. Predicting digestibility diets with internal markers: Evaluation of four potential markers. J. Anim. Sci. 63:1476-1483.

Couvreur, S., C. Hurtaud, C. Lopez, L. Delaby, and J. L. Peyraud. 2006. The linear relationship between the proportion of fresh grass in the cow diet, milk fatty acid composition, and butter properties. J. Dairy Sci. 89:1956-1969.

da Silva, D. C., G. T. Santos, A. F. Branco, J. C. Damasceno, R. Kazama, M. Matsushita, J. A. Horst, W. B. R. dos Santos, and H. V. Petit. 2007. Production performance and milk composition of dairy cows fed whole or ground flaxseed with or without monensin. J. Dairy Sci. 90:2928-2936.

da Silva-Kazama, D. C., G. T. Santos, P. T. M. Pintro, J. V. Visentainer, R. Kazama, H. V. Petit, and F. E. De Marchi. 2010. Effect of storage on fatty acid profile of butter from cows fed whole or ground flaxseed with or without monensin. R. Bras. Zootec. 39:2297-2303.

da Silva-Kazama, D. C., C. Cortes, R. Kazama, C. Benchaar, G. T. Santos, L. M. Zeoula, and H. V. Petit. 2011. Ruminal fermentation characteristics and fatty acid profile of ruminal fluid and milk of dairy cows fed flaxseed hulls supplemented with monensin. J. Dairy Res. 78:56-62.

Detmann, E., M. F. Paulino, J. T. Zervoudakis, S. C. Valadares Filho, R. F. Euclydes, R. P. Lana, and D. S. Queiroz. 2001. Chromium and internal markers on intake of mestizos steers supplemented on pasture. Rev. Bras. Zootec. 30:1600-1609.

dos Santos, W. B. R., G. T. D. Santos, D. C. da Silva-Kazama, U. Cecato, F. E. De Marchi, J. V. Visentainer, and H. V. Petit. 2011. Production performance and milk composition of grazing dairy cows fed pelleted or non-pelleted concentrates treated with or without lignosulfonate and containing ground sunflower seeds. Anim. Feed Sci. Technol. 169:167-175.

Duffield, T. F., A. R. Rabiee, and I. J. Lean. 2008. A meta-analysis of the impact of monensin in lactating dairy cattle. Part 2. Production effects. J. Dairy Sci. 91:1347-1360.

Fernandez, M. L. and D. Webb. 2008. Review: The LDL to HDL cholesterol ratio as a valuable tool to evaluate coronary heart disease risk. J. Am. Coll. Nut. 27:1-5.

Fürst, P. 2002. The striking diet of the island of Crete: lipid nutrition from the palaeolithic to the affluent modern society. Clin. Nutr. 21:9-14.

Gandra, J. R., F. P. Renno, J. E. de Freitas, M. V. dos Santos, L. F. P. E. Silva, and A. P. C. de Araujo. 2010. Productive performance and milk protein fraction composition of dairy cows supplemented with sodium monensin. R. Bras. Zootec. 39:1810-1817.

Hall, M. B. 2000. Neutral detergent-soluble carbohydrates: Nutritional relevance and analysis, a laboratory manual.
Extension Bulletin, 339. University of Florida, Gainesville, FL, USA.

Hurtaud, C., F. Faucon, S. Couvreur, and J. L. Peyraud. 2010. Linear relationship between increasing amounts of extruded linseed in dairy cow diet and milk fatty acid composition and butter properties. J. Dairy Sci. 93:1429-1443.

Institute of Medicine. 2002. Dietary Reference Intakes (DRIs) for energy, carbohydrate, fiber, fat, fatty acids, cholesterol, protein, and amino acids. National Academy Press. Part 1. Washington, DC, USA.

Ipharraguerre, I. R. and J. H. Clark. 2003. Usefulness of ionophores for lactating dairy cows: A review. Anim. Feed Sci. Technol. 106:39-57.

ISO (International Organization for Standardization). 1978. Animal and vegetable fats and oils - Preparation of methyl esters of fatty acids. https://www.iso.org/obp/ui/\#iso:std:iso:12966:-1:ed-1:v1:en Accessed March 30, 2015.

Lana, R. D. P. and J. B. Russell. 2001. Effects of monensin on fermentation and sensitivity of ruminal bacteria from bovine fed high concentrate or forage diets. Rev. Bras. Zootecn. 30:254-260.

Mensink, R. P., P. L. Zock, A. D. M. Kester, and M. B. Katan. 2003. Effects of dietary fatty acids and carbohydrates on the ratio of serum total to HDL cholesterol and on serum lipids and apolipoproteins: A meta-analysis of 60 controlled trials. Am. J. Clin. Nutr. 77:1146-55.

Mohammed, R., S. M. McGinn, and K. A. Beauchemin. 2011. Prediction of enteric methane output from milk fatty acid concentrations and rumen fermentation parameters in dairy cows fed sunflower, flax, or canola seeds. J. Dairy Sci. 94:6057-6068.

Nagarajara, T. G., C. J. Newbold, C. J. Van Nevel, and D. I. Demeyer. 1997. Manipulation of ruminal fermentation. In: (Eds. P. N. Hobson, and C. S. Stewart). The rumen microbial ecosystem. 2nd ed. Great Britain: Blackie Academic \& Professional, Aberdeen, Scotland, UK. pp. 524-632.

Neves, C. A., W. B. R. dos Santos, G. T. D. Santos, D. C. da Silva, C. C. Jobim, F. S. Santos, J. V. Visentainer, and H. V. Petit. 2009. Production performance and milk composition of dairy cows fed extruded canola seeds treated with or without lignosulfonate. Anim. Feed Sci. Technol. 154:83-92.

Neves, C. A., G. T. Santos, M. Matsushita, E. M. Alves, R. L. Oliveira, A. F. Branco, D. C. da Silva, A. C. Furlan, and H. V. Petit. 2007. Intake, whole tract digestibility, milk production, and milk composition of Holstein cows fed extruded soybeans treated with or without lignosulfonate. Anim. Feed Sci. Technol. 134:32-44.

National Research Council. 2001. Nutrient Requirements of Dairy Cattle. 7th Ed. National Academy Press, Washington, DC, USA.

Oba, M. and M. S. Allen. 2003. Dose-response effects of intrauminal infusion of propionate on feeding behavior of lactating cows in early or midlactation. J. Dairy Sci. 86:29222931.

Oeffner, S. P., Y. Qu, J. Just, N. Quezada, E. Ramsing, M. Keller, G. Cherian, L. Goddick, and G. Bobe. 2013. Effect of flaxseed supplementation rate and processing on the production, fatty acid profile, and texture of milk, butter, and cheese. J. Dairy 
Sci. 96:1177-1188.

Petit, H. V. 2010. Review: Feed intake, milk production and milk composition of dairy cows fed flaxseed. Can J. Anim. Sci. 90:115-127.

Riaz, M. N. 2000. Chemical and nutritional changes in food. In: Extruders in Food Applications (Ed. M. N. Riaz). CCR Press, Boca Raton, FL, USA. pp. 127-142.

Ruiz, R., G. L. Albrecht, L. O. Tedeschi, G. Jarvis, J. B. Russell, and D. G. Fox. 2001. Effect of monensin on the performance and nitrogen utilization of lactating dairy cows consuming fresh forage. J. Dairy Sci. 84:1717-1727.

Schroeder, G. F., G. A. Gagliostro, F. Bargo, J. E. Delahoy, L. D. Muller. 2004. Effects of fat supplementation on milk production and composition by dairy cows on pasture: A review. Livest. Prod. Sci. 86:1-18.

Schwingshackl, L. and G. Hoffmann. 2014. Dietary fatty acids in the secondary prevention of coronary heart disease: a systematic review, meta-analysis and meta-regression. BMJ Open. 4(4):e004487.

Shingfield, K. J., L. Bernard, C. Leroux, and Y. Chilliard. 2010. Role of trans fatty acids in the nutritional regulation of mammary lipogenesis in ruminants. Animal 4:1140-1166.
Smith, A. M. and J. T. Reid. 1955. Use of chromic oxide as an indicator of fecal output for the purpose of determining the intake of pasture herbage by grazing cows. J. Dairy Sci. 38:515-524.

Parodi, P. W. 2009. Milk fat nutrition. Dairy Fats and Related Products (Ed A. Y. Tamime). Wiley-Blackwell, Oxford, UK. p. 344

Van Soest, P. J., J. B. Robertson, and B. A. Lewis. 1991. Methods for dietary fiber, neutral detergent fiber, and nonstarch polysaccharides in relation to animal nutrition. J. Dairy Sci. 74:3583-3597.

Weiss, W. P., H. R. Conrad, and N. R. St. Pierre. 1992. A theoretically-based model for predicting total digestible nutrient values of forages and concentrates. Anim. Feed Sci. Technol. 39:95-110.

Willians, C. H., D. J. David, and O. Iisma. 1962. The determination of chromic oxide in faeces samples by atomic absorption spectrophotometry. J. Agric. Sci. 59:381-385.

Yang, Z. H., H. Miyahara, and A. Hatanaka. 2011. Chronic administration of palmitoleic acid reduces insulin resistance and hepatic lipid accumulation in $\mathrm{KK}-\mathrm{A}^{\mathrm{y}}$ mice with genetic type 2 diabetes. Lipids Health Dis. 10:120-128. 